\title{
Trenger vi eksamen?
}

\author{
Hvilken læring er den viktige i medisinstudiet? I disse dager, da medisinstudiet er under revidering i flere \\ byer, bør dette spørsmålet reises -ikke minst i Oslo, der jeg selv studerer på 5. året.
}

Opptil flere av våre undervisere har stilt oss uformelle spørsmål om hva vi studenter ønsker oss mer eller mindre av. Når jeg sier at jeg ønsker å avskaffe eksamen, stilner diskusjonen, eller jeg blir møtt med en mild latter. Et slikt forslag kan vel ikke diskuteres på alvor? Men disse spørsmålene er saklige: Er eksamen et godt læringsvirkemiddel? Hva slags læring fremmer eksamensinstituttet? Kunne man greid seg bedre uten? I Oslo har vi minst én eksamen hvert semester. Hvordan påvirker dette den totale læringen gjennom studiet?

Vi må anta at fakultetene arrangerer eksamen fordi det alltid har vært slik. Like fullt kan jeg forestille meg to legitime formål med eksamen. Det første er å motivere studentene til å erverve kunnskap de ellers ikke ville ha ervervet, det andre er å sikre at studentene går ut av studiet uten graverende kunnskapshull som vil medføre en medisinsk risiko i legegjerningen.

Imidlertid virker det som om eksamensinstituttet bare delvis tjener disse formål og at de kunne ivaretas med andre midler. Det finnes for eksempel ingen eksamen på den nyutdannede leges vei frem til spesialistgodkjenning. Likevel finnes det mekanismer som langt på vei sørger for at leger i spesialisering ikke utgjør noen medisinsk risiko underveis i læringsforløpet.

Jeg har inntrykk av at en stor del av kunnskapen man erverver seg gjennom ulystbetont pugging i forkant av en eksamen, er kunnskap man senere glemmer eller ikke får nyttiggjort seg. Den kunnskapen man virkelig får bruk for, er i stor grad ervervet gjennom interessebasert læring. Slik læring er også lystbetont.

\section{Ikke nye tanker}

Disse tankene er ikke nye, og det finnes en omfattende litteratur om emnet som jeg ikke skal gå inn på i denne kommentaren. Da jeg var redaktør i AEsculap, et magasin for medisinstudenter og leger, publiserte vi imidlertid flere artikler om studieplaner og reformer, og vi intervjuet tidligere og sittende dekaner. I forarbeidet til en av

\section{«En stor del av kunn- skapen man erverver seg gjennom ulyst- betont pugging i forkant av en eksamen, er kunnskap man senere glemmer eller ikke får nyttiggjort seg»}

disse artiklene (1) fikk vi opplyst at det under utarbeiding av studieplanen Oslo 96 ble diskutert om man i det hele tatt skulle ha eksamen.

Da Tromsø fikk studieplan i 1973 var det, i tråd med populære tankestrømninger på den tiden, ingen eksamener de første fire årene. Riktignok var strykprosenten svært høy på den første eksamenen etter fire år, men ble studentene som gikk fire år i Tromsø uten eksamen dårligere leger? Etter min mening representerte denne trenden $\mathrm{i}$ begynnelsen av 1970-årene et fremskritt for pedagogikken spesielt og for samfunnet generelt. Jeg er interessert $\mathrm{i}$ å forstå hvorfor man gikk vekk fra den radikale tenkningen som hersket den gang.

En av hovedutfordringene for fremtidens leger vil trolig være å motstå et stadig større press fra politikerne, forvaltningen og forskningsindustrien. Den enkelte leges selvstendighet og kritiske tenkning vil være avgjørende ressurser for å kunne verne om legens og medisinfagets autonomi - ellers risikerer legen å bli redusert til en byråkrat som forvalter pasientens rettigheter. Da trengs det et mest mulig akademisk studium der studentene lærer å ta ansvar for egen læring og ikke forholder seg til utdanningen som en «skole», slik altfor mange gjør i dag. I så måte er gjeninnføringen av karakterer ved medisinsk fakultet ved Universitetet i Oslo et skritt i gal retning - det forsterker skolepreget som utdanningen allerede har.

Jeg savner debatt og engasjement rundt læringsformer i medisinstudiet. Spørsmålet om hvorvidt eksamensinstituttet fremmer verdifull læring eller ikke, kan være et sted å starte. Men dagens leger og studenter er kanskje ikke modne for å diskutere dette spørsmålet på et saklig plan? Da sitter vi igjen med det underforståtte, lommeruskfornuftige og masochistiske mantraet om at «alle forstår hvorfor eksamen er nødvendig».

\section{Tore Kierulf Næss \\ torekierulfnaess@hotmail.com}

Tore Kierulf Næss (f. 1973) studerer medisin på 9. semester ved Universitet i Oslo. Han er magister i filosofi og har arbeidet som ex.phil.lærer, skribent, kunstkritiker og tidsskriftredaktør. Han var redaktør for ÆEsculap i årene 2011-13.

Forfatter har fylt ut ICMJE-skjemaet og oppgir ingen interessekonflikter.

\section{Litteratur}

1. Næss TK, Tunheim K. Da positivismestriden kom til medisinsk fakultet. ÆEsculap 2011; nr. 1: 10.

Mottatt 13.5. 2014, første revisjon innsendt 25.5. 2014, godkjent 2.6. 2014. Redaktør: Hanne Støre Valeur.

Publisert først på nett. 